reasonable limits of possibility. He who would revive this creed must offer new facts.

[From the Chicago laboratory of the Referee Board of Consulting ScienTIFTC EXPERTS to THE U. S. DepartMent OF Agriculture,

NORTHWESTERN UNIVERSITY MEDICAL SCHOOL.]

\title{
THE ESTIMATION OF UREA IN URINE.
}

Stakley R. Benedict and Frank gephart.

Bunsen ${ }^{2}$ showed many years ago that if solutions of urea are heated to high temperatures the urea is converted entirely into anmonia and carbon dioxide. Many methods for the estimation of urea have been proposed which are based upon this fact. In the process for urea estimation most commonly employed at the present time, viz., that of Folin, ${ }^{2}$ the decomposition is secured through a high temperature obtained by boiling the solution after the addition to it of a considerable quantity of magnesium chloride. The digesting mixture is kept neutral or slightly acid through the frequent addition of small quantities of hydrochloric acid.

Where a number of decompositions are to be carried out simultaneously, the technique involved in Folin's method is laborious, and the results sometimes uncertain, owing to the difficulty of keeping conditions entirely uniform as to temperature and acidity. The employment of a magnesium salt in a method involving the distillation of ammonia from the mixture is unfortunate. Magnesium chloride is seldom obtained free from ammonia and is so hygroscopic that difficulty in uniform sampling introduces a distinct source of error. Kober has recently called attention to the great difficulty of completely distilling anmonia from solutions containing magnesiun salts. The distillation in Folin's process must be prolonged and carried almost to dryness, yet if continued too far, some of the excess of magnesium chloride is decomposed, with the liberation of acid, thus ruining the determination. When carried out with due regard to securing exactly sinilar conditions, Folin's process yields very uniform results.

The following method for urea estimation has been thoroughly tested for several weeks during the course of some nutrition experiments carried out in this laboratory. It permits of thirty or more decompositions being carried out simultaneously, as readily as one involves no special technique, shortens the time of subsequent distillation, and secures uniform conditions for the digestions. The procedure is as follows: Five

${ }^{2}$ Bunsen, Ann., 65, 375 .

${ }^{2}$ Folin, Z.physiol. Chem., 32, 504 (1901); 36, 333 (1902); 37, 548 (1903). Also Am. J. Physiol, I3, 45-47.

${ }^{3}$ Kober, This Journal, 30, 1279 (August, rgo8). 
cubic centimeters of urine, together with an equal volume of dilute hydrochloric acid ${ }^{1}$ (made by adding four volumes of distilled water to one volume of the concentrated acid) are introduced into a rather wide test tube. The mouth of the tube is covered with a cap made by folding a piece of lead-foil over the top, ${ }^{2}$ and is then placed in a small autoclave which is heated to a temperature of $150^{\circ}-155^{\circ}$ (corresponding to a pressure of about six kilograms per square centimeter). This temperature is maintained for about an hour and a half. After the autoclave has cooled, the contents of the tube are washed into an $800 \mathrm{cc}$. Kjeldahl distillation flask, diluted to about $400 \mathrm{cc}$, treated with $20 \mathrm{cc}$. of ten per cent. sodium hydroxide solution and distilled for about forty minutes into an excess of standard acid. The residue of acid is titrated and the urea nitrogen calculated (after subtraction of the previously determined ammonia nitrogen).

The following work has been done to test the efficiency of this method. Pure urea solutions were prepared of two and one half and five per cent. strength, and their nitrogen content determined by Kjeldahl's, Folin's and the autoclave process. Titrations of the ammonia obtained by the three methods were concordant to within $0.2 \mathrm{cc}$. of $\mathrm{N} / \mathrm{ro}$ solution. The following is a record of a typical titration, five cubic centimeters of urea solution being used in each case.

\begin{tabular}{|c|c|c|}
\hline Method used. & $\begin{array}{l}\text { N/ro acid neutralized, } \\
\text { sc. }\end{array}$ & $\begin{array}{l}\text { Nitrogen, } \\
\text { gm. }\end{array}$ \\
\hline Kjeldah1. . & $\ldots 41.00$ & 0.0574 \\
\hline Folin..... & $\ldots .40 .90$ & 0.0572 \\
\hline Writers' pr & $\ldots .41 .10$ & 0.0575 \\
\hline
\end{tabular}

The results obtained with pure urea solutions left no doubt that urea is completely converted into ammonia and carbon dioxide by the writers' process.

The urea content of about seventy-five urines was deternined by Folin's and the writers' method. These urines represented, in almost every case, the total twenty-four hour output for one individual, diluted to $2000 \mathrm{cc}$. The total nitrogen content of these urines varied between five and fifteen grams. The results obtained by the autoclave process were almost invariably from $0.1 \mathrm{cc}$. to $0.4 \mathrm{cc}$. of $\mathrm{N} / 4$ acid higher than by Folin's method. The slightly higher results must be held to indicate either that the autoclave procedure decomposes other nitrogenous urinary constituents than urea, or that Folin's process fails to obtain all the urea nitrogen as ammonia. It is difficult to see, from the theoretical side,

1 When the method was first worked out concentrated hydrochloric acid was employed. Subsequent work has shown that identical results are obtained with the dilute acid.

2 The tube may be conveniently labeled by writing the number deeply into the lead-foil cap with a pencil. 
how the procedure followed in the writers' process should decompose a compound or compounds left unaffected by Folin's procedure. The temperature employed in the two processes is almost the same; furthermore, we have found that the temperature of the autoclave may be varied between $170^{\circ}$ and $160^{\circ}$ without affecting the results. The acidity of the digesting mixture is probably somewhat greater in the writers' method than in that of Folin, and this acidity is maintained practically constant throughout, while in Folin's process the solution becomes neutral, acid, and alkaline by turns. If either of those procedures decomposed additional constituents of the urine we should expect it to occur in Folin's process rather than in the other. Furthermore, the acidity in the writers' process can be varied within wide limits, as mentioned in a preceding footnote in this paper, without altering the results. The distillation in the autoclave process is carried out in presence of a slight excess of sodium hydroxide, rather than in the presence only of magnesiun hydroxide, as is true of Folin's method. The alkalinity is, however, considerable in both cases and inasmuch as the distillation is continued more than twice as long in Folin's process as in our own, it is not likely that complete decomposition of one or more urinary compounds should occur in the latter process which entirely escape in the former. The duplicates obtained by the writers' process are so perfect as to exclude any question of partial decomposition. As further evidence that the slightly greater alkalinity in our process is not responsible for the higher results we may mention the fact that the excess of 10 per cent. sodium hydroxide present may be varied between $5 \mathrm{cc}$. and $25 \mathrm{cc}$. without affecting the results. The large quantity of magnesium chloride present during Folin's procedure, might hinder perfect decomposition and distillation in so complex a fluid as the urine. In order to throw some light upon this point we have carried out digestions in the autoclave both in presence and absence of magnesium chloride and compared these results with those obtained from the same urines by I'olin's process. The figures obtained seen to indicate without question that the magnesium salt is the essential feature in the production of the different results by the two methods. The following may be cited as typical titrations by the autoclave process, with and without magnesium chloride, as compared with results from the same urines obtained by Folin's method.

The first of these tables gives typical results by the two processes. Those by the autoclave, in absence of magnesium chloride, are always appreciably higher than by Folin's method. In the second table however, where the autoclave digestion and the subsequent distillation were carried out in the presence of magnesium salt, the results by the two methods are reasonably good duplicates for either method alone, plus and minus variations occurring for either method, a result never thus far obtained 
when the autoclave digestion was carried out in absence of magnesium chloride.

\begin{tabular}{|c|c|c|c|c|}
\hline \multicolumn{5}{|c|}{ EXPERIMENT I. } \\
\hline $\begin{array}{l}\text { No. of } \\
\text { sample. }\end{array}$ & $\begin{array}{l}\text { Results by } \\
\text { Folin's process. } \\
\text { cc. N/4 acid } \\
\text { neutralized from } \\
5 \mathrm{cc} \text {. urine. }\end{array}$ & $\begin{array}{l}\text { Results by writers' } \\
\text { process. (No } \mathrm{MgCl}_{2} \\
\text { preseut.) } \\
\text { cc. N/4 acid } \\
\text { neutralized from } \\
5 \mathrm{cc} \text {. urine. }\end{array}$ & $\begin{array}{l}\text { Total } \\
\text { urea N by } \\
\text { Folin's } \\
\text { process. } \\
\text { Gram. }\end{array}$ & $\begin{array}{l}\text { Total } \\
\text { urea N by } \\
\text { writers' } \\
\text { process. } \\
\text { Gram. }\end{array}$ \\
\hline \multicolumn{2}{|c|}{$1 \ldots \ldots \ldots \ldots \ldots 7.90$} & $8 . \infty$ & 10.69 & 10.83 \\
\hline \multicolumn{2}{|c|}{$2 \ldots \ldots \ldots \ldots \ldots 7 \cdot 50$} & 7.65 & 10.03 & 10.24 \\
\hline \multirow{2}{*}{\multicolumn{2}{|c|}{$\begin{array}{l}3 \ldots \ldots \ldots \ldots \ldots \ldots, 7 \cdot 50 \\
4 \ldots \ldots \ldots \ldots \ldots, 8.00\end{array}$}} & $7 \cdot 75$ & 9.87 & 10.22 \\
\hline & & 8.35 & 10.67 & II I I 7 \\
\hline \multicolumn{2}{|c|}{$5 \ldots \ldots \ldots \ldots \ldots 7 \cdot 15$} & $7 \cdot 50$ & $9 \cdot 43$ & 9.92 \\
\hline \multicolumn{2}{|c|}{$6 \ldots \ldots \ldots \ldots, 7 \cdot 30$} & 7.65 & $9 \cdot 79$ & 10.28 \\
\hline \multicolumn{5}{|c|}{ EXPERIMENT II. } \\
\hline $\begin{array}{r}\text { No, of } \\
\text { sample }\end{array}$ & $\begin{array}{c}\text { Results by } \\
\text { Folin's process. } \\
\text { cc. N/4 acid } \\
\text { neutralized from } \\
5 \text { cc. uritse. }\end{array}$ & $\begin{array}{l}\text { Results by writers' } \\
\text { process in presence. } \\
\text { of } 20 \text { gms. MgCl. } \\
\text { cc. N/4 acid neutral- } \\
\text { ized from } 5 \text { cc. urine. }\end{array}$ & $\begin{array}{l}\text { Total } \\
\text { urea N by } \\
\text { Folin's } \\
\text { process. } \\
\text { Gram. }\end{array}$ & $\begin{array}{l}\text { Total } \\
\text { urea N by } \\
\text { writers' } \\
\text { process. } \\
\text { Gram. }\end{array}$ \\
\hline \multirow{2}{*}{\multicolumn{2}{|c|}{$\begin{array}{l}7 \ldots \ldots \ldots \ldots \ldots \ldots \\
8 \ldots \ldots \ldots \ldots \ldots\end{array}$}} & $8 . \infty$ & 10.46 & 10.67 \\
\hline & & 6.05 & 8.16 & 8.09 \\
\hline \multicolumn{2}{|c|}{$9 \ldots \ldots \ldots \ldots 6.95$} & 6.85 & $9.1 \mathrm{I}$ & 8.97 \\
\hline \multicolumn{2}{|c|}{ I0............ $5 \cdot 70$} & $5 \cdot 75$ & $7 \cdot 44$ & $7 \cdot 52$ \\
\hline \multicolumn{2}{|c|}{$15 \ldots \ldots \ldots \ldots 7 \cdot 30$} & $7 \cdot 4^{\circ}$ & 9.68 & 9.83 \\
\hline \multicolumn{2}{|r|}{$\cdots 7.05$} & 7.15 & 9.29 & $9 \cdot 43$ \\
\hline
\end{tabular}

The facts indicated from an examination of the above tables should have an important bearing upon urea estimation. The increase of nitrogen obtained when the digestion and distillation is carried out in absence of the magnesium salt may be as high as from one to three per cent. of the total urinary nitrogen. The rôle of the magnesium salt in this connection is certainly peculiar. Theoretically we must assume either that the magnesium salt in hibits the decomposition of some other nitrogenous constituent which is completely decomposed in its absence, while permitting a smooth decomposition of urea into ammonia and the subsequent complete removal of this ammonia by distillation, a view which appears so unlikely as to deserve no consideration until experimental evidence in its favor can be offered, or we must conclude that all of the urea nitrogen in urine cannot be obtained as distillable ammonia nitrogen, when the digestion and distillation are carried out in presence of an excess of magnesium chloride. The absolute validity of this statement can only be tested by subsequent work. Either line of values can be obtained by the autoclave method, depending upon whether the magnesium salt is present or not. In view of the fact that from lack of an adequate control method, Folin has not been able to demonstrate conclusively that his process obtains all of the urinary urea nitrogen, it would appear that in the present state of knowledge regarding the subject the autoclave 
results obtained in the absence of magnesium salt are probably the correct ones.

It is hoped to present a later paper which will go into further details concerning the method for urea estimation described above, as applied under various conditions, and which will discuss further the probable value of this method in comparison with that of Folin.

chicago, ill.

\section{STUDIES IN NITRATION, V. MELTING POINTS OF MIXTURES OF ORTHO - AND PARANITRANILINES. ${ }^{1}$}

By J. Bishop Tingle and H. F. ROLKer.

In the second paper of this series, "we gave the results of our determinations of the melting points of mixtures of ortho- and meta- and of metaand paranitranilines. We also showed that the curves obtained by

Table of the Melting Points of Mixtures of Ortho- and Paranitraniline.

\begin{tabular}{|c|c|c|c|c|c|c|c|}
\hline $\begin{array}{l}\text { Per cent. } \\
\text { of ortho. }\end{array}$ & $\begin{array}{l}\text { Percent } \\
\text { of para. }\end{array}$ & M. P. & $\begin{array}{l}\text { M.P. after having } \\
\text { been melted and } \\
\text { quickly cooled. }\end{array}$ & $\begin{array}{l}\text { Per cent. } \\
\text { of ottho. }\end{array}$ & $\begin{array}{l}\text { Percent. } \\
\text { of para. }\end{array}$ & M. P. & $\begin{array}{l}\text { P. after having } \\
\text { been melted and } \\
\text { quickly cooled }\end{array}$ \\
\hline 98 & 2 & $68.5^{\circ}$ & $68.0^{\circ}$ & 48 & $5^{2}$ & $103.0^{\circ}$ & $102.0^{\circ}$ \\
\hline 96 & 4 & $67.0^{\circ}$ & $67.0^{\circ}$ & 46 & 54 & $104.0^{\circ}$ & $104.0^{\circ}$ \\
\hline 94 & 6 & $66.0^{\circ}$ & $67.0^{\circ}$ & 44 & 56 & $\log .0^{\circ}$ & I I $5.0^{\circ}$ \\
\hline $9^{2}$ & 8 & $66.5^{\circ}$ & $66.0^{\circ}$ & 42 & $5^{8}$ & $112.0^{\circ}$ & $\operatorname{II} 3.0^{\circ}$ \\
\hline 90 & I0 & $64.0^{\circ}$ & $64.0^{\circ}$ & 40 & 60 & I $15.0^{\circ}$ & II $6.0^{\circ}$ \\
\hline 88 & I2 & $62.5^{\circ}$ & $63 \cdot 5^{\circ}$ & 38 & 62 & $109.0^{\circ}$ & $\operatorname{I09} .0^{\circ}$ \\
\hline 86 & 14 & $61.0^{\circ}$ & $6 \mathrm{I} \cdot 5^{\circ}$ & 36 & 64 & $117.0^{\circ}$ & $121.0^{\circ}$ \\
\hline 84 & 16 & $63 \cdot 5^{\circ}$ & $60.5^{\circ}$ & 34 & 66 & $123.0^{\circ}$ & $122.0^{\circ}$ \\
\hline 82 & I 8 & $60.5^{\circ}$ & $60.0^{\circ}$ & 32 & 68 & $129.0^{\circ}$ & $130.0^{\circ}$ \\
\hline 80 & 20 & $61.0^{\circ}$ & $59 \cdot 5^{\circ}$ & 30 & 70 & $121.0^{\circ}$ & $122.0^{\circ}$ \\
\hline 78 & 22 & $62.0^{\circ}$ & $62.0^{\circ}$ & 28 & 72 & $127.5^{\circ}$ & I $28.0^{\circ}$ \\
\hline 76 & 24 & $61.0^{\circ}$ & $60.0^{\circ}$ & 26 & 74 & $127.0^{\circ}$ & $128.0^{\circ}$ \\
\hline 74 & 26 & $60.8^{\circ}$ & $61.0^{\circ}$ & 24 & 76 & $109.5^{\circ}$ & $114.0^{\circ}$ \\
\hline 72 & 28 & $61.0^{\circ 3}$ & $61.0^{\circ}$ & 22 & 78 & $131.0^{\circ}$ & $133.0^{\circ}$ \\
\hline 70 & 30 & $60.0^{\circ}$ & $72.0^{\circ}$ & 20 & 80 & $132.5^{\circ}$ & $134.0^{\circ}$ \\
\hline 68 & 32 & $60.0^{\circ}$ & $59.0^{\circ}$ & 18 & 82 & $139.0^{\circ}$ & $142.0^{\circ}$ \\
\hline 66 & 34 & $61.5^{\circ}$ & $59.0^{\circ}$ & 16 & 84 & $\mathrm{I} 35.0^{\circ}$ & $135.0^{\circ}$ \\
\hline 64 & 36 & $61.5^{\circ}$ & $86.0^{\circ}$ & 14 & 86 & $135.0^{\circ}$ & $137.0^{\circ}$ \\
\hline 62 & 38 & $62.0^{\circ}$ & $83.0^{\circ}$ & 12 & 88 & $137.0^{\circ}$ & $139.0^{\circ}$ \\
\hline 60 & 40 & $61.0^{\circ}$ & $85.0^{\circ}$ & 10 & 90 & $142.0^{\circ}$ & $141.5^{\circ}$ \\
\hline 58 & 42 & $98.0^{\circ}$ & $96.0^{\circ}$ & 8 & 92 & $141.5^{\circ}$ & $143.5^{\circ}$ \\
\hline 56 & 44 & $91.0^{\circ}$ & $90.0^{\circ}$ & 6 & 94 & $142.0^{\circ}$ & $144.0^{\circ}$ \\
\hline 54 & 46 & $\mathrm{IO}_{4} .0^{\circ}$ & $103.0^{\circ}$ & 4 & 96 & $144.8^{\circ}$ & I $45.5^{\circ}$ \\
\hline 52 & 48 & $93.0^{\circ}$ & $95.5^{\circ}$ & 2 & 98 & $147.0^{\circ}$ & $147.0^{\circ}$ \\
\hline 50 & 50 & $99.0^{\circ}$ & $99.0^{\circ}$ & . & . & & \\
\hline
\end{tabular}

Chem. J., 36, 605 (1906); Bishop Tingle and Rolker, THis Jovr.yal, 30, 822; Bishop Tingle and Blanck, Ibid., 30, 1395, I587 (Ig08).

${ }^{2}$ Loc. cit. After the proof had been revised the printers changed the name of the junior author to Roelker.-J. B. T.

${ }^{3}$ Somewhat indefinite 